J. Lake Sci. (湖泊科学), 2021, 33(6): 1675-1686

DOI 10. 18307/2021. 0606

(c) 2021 by Journal of Lake Sciences

\title{
生态补水对白洋淀流域地表水和地下水水化学特征的影响”
}

\author{
崔 旦 ${ }^{1,2}$, 张 兵 $^{1 * *}$, 何明霞 ${ }^{1,2}$, 夏文雪 ${ }^{1,2}$, 王义东 ${ }^{1}$, 赵 勇 $^{3}$ \\ (1: 天津师范大学天津市水资源与水环境重点实验室,天津 300387) \\ ( 2 : 天津师范大学地理与环境科学学院, 天津 300387 ) \\ (3: 中国水利水电科学研究院水资源研究所, 北京 100038)
}

\begin{abstract}
摘 要: 生态补水是维持和改善白洋淀生态环境的重要途径. 为研究生态补水对白洋淀水环境的影响, 分别在补水前与 补水后采集淀水、河水及地下水样品, 分析区域地表水和地下水水化学特征. 结果表明: (1) 白洋淀补水前、后地表水与 地下水的水化学组成中 $\mathrm{Na}^{+}$为主要阳离子, 补水后阴离子以 $\mathrm{HCO}_{3}^{-}$为主, 淀区南部地表水电导率高; 补水后地表水与地 下水 $\mathrm{Ca}^{2+} 、 \mathrm{Mg}^{2+}$ 和 $\mathrm{HCO}_{3}^{-}$浓度显著增加, 水体电导率降低. (2) 补水前地下水为 $\mathrm{Na}-\mathrm{HCO}_{3}$ 型水, 地表水主要为 $\mathrm{Na}-\mathrm{Cl} \cdot \mathrm{SO}_{4}$ 及 $\mathrm{Na}-\mathrm{Cl} \cdot \mathrm{HCO}_{3}$ 类型; 补水后地表水与浅层地下水向 $\mathrm{Ca} \cdot \mathrm{Mg}-\mathrm{HCO}_{3}$ 型演化, 深层地下水水化学类型基本保持不变. (3)生 态补水使白洋淀水位升高, 淀区水面积增大, 缓解了水资源短缺的问题; 同时也使浅层地下水水化学组成发生改变, 而 深层地下水暂未受到影响. 生态补水后, 受稀释和混合作用的影响, 水体 $\mathrm{Na}^{+} 、 \mathrm{Cl}^{-}$和 $\mathrm{SO}_{4}^{2-}$ 浓度显著下降, $\mathrm{Ca}^{2+} 、 \mathrm{Mg}^{2+}$ 及 $\mathrm{HCO}_{3}^{-}$浓度增加. 在白洋淀生态补水中应 “先治污, 后补水”, 以减少补水过程中污染物向淀区的运移, 还应注意区域地下 水位上升过程中的阳离子交换及水岩相互作用, 为合理调配生态补水及改善白洋淀生态环境提供科学依据.
\end{abstract}

关键词: 水化学;生态补水;地表水; 地下水;白洋淀流域

\section{Impacts of ecological water replenishment on the hydrochemical characteristics of surface water and groundwater in Lake Baiyangdian Watershed*}

\author{
Cui $\mathrm{Xu}^{1,2}$, Zhang Bing ${ }^{1 * *}$, He Mingxia ${ }^{1,2}$, Xia Wenxue ${ }^{1,2}$, Wang Yidong ${ }^{1} \&$ Zhao Yong $^{3}$ \\ (1: Tianjin Key Laboratory of Water Environment and Resources, Tianjin Normal University, Tianjin 300387, P.R.China) \\ (2: School of Geographic and Environmental Sciences, Tianjin Normal University, Tianjin 300387, P.R. China) \\ (3: Department of Water Resources, China Institute of Water Resources and Hydropower Research, Beijing 100038, P.R.China)
}

\begin{abstract}
Ecological water replenishment is an important way to maintain and improve the ecological environment of Lake Baiyangdian Watershed. In order to study the impact of ecological water replenishment on the water environment of Lake Baiyangdian Watershed, the samples of lake water, river water and groundwater were collected before and after ecological water replenishment respectively, and the hydrochemical characteristics of surface water and groundwater were analyzed. The results showed that: (1) Before and after ecological water replenishment, sodium-ion was the main cation in the hydrochemical composition of surface water and groundwater; bicarbonate radical-ion was the main anion after ecological water replenishment, and the conductivity of surface water in the south of Lake Baiyangdian was high. After ecological water replenishment, the mass concentrations of calcium-ion, magnesium-ion and bicarbonate radical-ion in surface water and groundwater increased significantly, the water conductivity decreased. (2) Before ecological water replenishment, the groundwater was $\mathrm{Na}-\mathrm{HCO}_{3}$ type, and the surface water was mainly $\mathrm{Na}-\mathrm{Cl} \cdot$ $\mathrm{SO}_{4}$ and $\mathrm{Na}-\mathrm{Cl} \cdot \mathrm{HCO}_{3}$ types; After ecological water replenishment, the surface water and shallow groundwater evolved into $\mathrm{Ca} \cdot \mathrm{Mg}$ $\mathrm{HCO}_{3}$ type, and the hydrochemical types of deep groundwater were basically unchanged. (3) Ecological water replenishment increased the water level and water area of Lake Baiyangdian, alleviating the problem of water shortage; meanwhile, the hydrochemical composition of shallow groundwater was changed, while the deep groundwater was not affected. After ecological water replenish-
\end{abstract}

* 2020-11-14 收稿; 2021-03-24 收修改稿.

国家自然科学基金项目 (41971037) 和国家杰出青年科学基金项目 (52025093) 联合资助.

** 通信作者; E-mail: zhangbing@ tjnu.edu.cn. 
ment, the concentrations of sodium-ion, chloridion-ion and sulfate-ion decreased significantly, while the concentrations of calciumion, magnesium-ion and bicarbonate radical-ion increased. In addition, the cation exchange and water rock interaction in the rising process of regional groundwater level should be paid attention to, so as to provide scientific basis for rational allocation of ecological water replenishment and improvement of ecological environment of Lake Baiyangdian watershed.

Keywords: Hydrochemistry; ecological water replenishment; surface water; groundwater; Lake Baiyangdian Watershed

湿地被誉为 “地球之肾”, 它是由水陆生态系统相互作形成的生态系统, 在维系地区生态平衡, 推动经济 社会发展中具有不可替代的地位 ${ }^{[1-3]}$. 近年来, 在人类活动与全球气候变化的综合影响下, 湿地面临着生态 环境恶化、面积持续萎缩以及水体污染严重等危机 ${ }^{[4]}$. 充足的水源是保障湿地水环境及生态服务功能的基 础. 跨流域调水可以改善水资源时空分布不均,缓解区域水资源供需矛盾 ${ }^{[5]}$. 通过跨流域调水向湿地生态水 网补水, 可以修复、改善其受损的生态系统结构与功能, 使湿地自我调节能力得到恢复, 对维持湿地生态系 统生态平衡起到至关重要的作用.

人类活动会对湿地水环境产生深远影响. 目前, 人类工、农业活动对白洋淀水生态产生影响的研究已较 为深人, 主要包括: 水质时空变化 ${ }^{[6-7]}$ 、湿地景观格局变化 ${ }^{[8]}$ 、水体富营养化监测 ${ }^{[9-10]}$ 、污染物的特征与溯 源 ${ }^{[1-12]}$ 以及水生生物对人类活动的响应 ${ }^{[13]}$ 等方面. 水化学是水体的基本要素之一, 分析水体水化学特征可 以表征其环境化学特点、水质状况、水体离子来源、分布及迁移转化规律. 生态补水在增加受水区地表水水 量、涵养和修复地下水资源、提升地表水与地下水水位 ${ }^{[14-15]}$ 、改善淀区水动力状况 ${ }^{[16]}$ 和水质 ${ }^{[17]}$ 的同时, 也会 使区域地表水与地下水的水化学类型发生改变 ${ }^{[18-19]}$. 研究生态补水条件下水体水化学变化, 可为受水区水 环境及生态的修复或进行合理的农业灌溉提供理论支撑.

白洋淀是华北平原最大的淡水湿地生态系统. 自 1960 年以来, 气候、水文等自然因素, 以及工农业与生 活用水量加大、污水排放、上游建设水利工程设施以及地下水的过度开采等人为因素, 导致区域水环境逐渐 恶化 ${ }^{[6,20]}$. 白洋淀湿地景观破碎化、干化问题严重 ${ }^{[21]}$, 水体富营养化和沼泽化问题并存, 污染物总量居高不 下,水质长期处于 $\mathrm{I} \sim$ 劣 $\mathrm{V}$ 类之间 ${ }^{[22-23]}$. 2017 年 4 月 1 日, 中共中央、国务院设立雄安新区, 白洋淀在其建设 过程中具有调节区域气候、优化地区生态环境的重要功能. “建设雄安新区,一定要把白洋淀修复好、保护 好”. 水是白洋淀生态之基, 向淀区补水以恢复白洋淀“华北之肾”功能的任务迫在眉睫. 截至 2020 年,共向 白洋淀补水约 $197.6 \times 10^{8} \mathrm{~m}^{3}$. 近年来国内外学者对白洋淀生态补水量 ${ }^{[24-25]}$ 、配水水源路径 ${ }^{[26]}$ 及补水对区域 水动力的影响 ${ }^{[16]}$ 等方面进行了大量研究, 也对补水方案产生的生态效益进行了评价 ${ }^{[27-28]}$. 作为生态补水的 典型受水区域,有关多水源长效补水机制对白洋淀地表水与地下水水化学组成的影响方面的研究仍需深人.

2018 年 4 月 16 日- 6 月 22 日, “南水北调” 中线工程首次通过瀑河及北易水退水闸向白洋淀进行生态 补水, 补水量为 $1 \times 10^{8} \mathrm{~m}^{3}$. 同年 4 月 5 日 -6 月 5 日, 王快水库和西大洋水库向白洋淀补水 $2.8 \times 10^{7} \mathrm{~m}^{3}$. 本文 通过野外采样和室内测试, 分析 2018 年白洋淀淀水、河水及地下水生态补水前、后水化学时空分布特征及 离子来源, 阐释生态补水对地表水和地下水水化学特征的影响机理, 探讨生态补水对未来白洋淀水环境可 能产生的影响, 以期为白洋淀水体生态环境改善及雄安新区生态核心区的保护与治理提供科学依据.

\section{1 研究区概况}

白洋淀 ( $38^{\circ} 44^{\prime} \sim 38^{\circ} 59^{\prime} \mathrm{N}, 115^{\circ} 45^{\prime} \sim 116^{\circ} 07^{\prime} \mathrm{E}$ ) 地处河北省雄安新区, 总面积为 $366 \mathrm{~km}^{2}$, 由 143 个淀泊 与沟壕组成, 是华北平原最大的淡水湿地 ${ }^{[20]}$ (图 1a). 流域地处暖温带半湿润大陆季风气候区, 夏季炎热多 雨, 冬季寒冷干燥, 多年年平均气温为 $12.8^{\circ} \mathrm{C}$, 多年年平均降水量为 $524.8 \mathrm{~mm}$, 多年年平均水面蒸发量达 $1369 \mathrm{~mm}^{[21]}$. 气温、降水量与蒸发量年内变化较大, 夏季 (6-9 月) 月均温度均大于 $20^{\circ} \mathrm{C}$, 其中 7 月平均温度 高达 $26.9^{\circ} \mathrm{C}$, 约 67\% 的降雨集中于 6-9 月. 流域地势呈现西北高、东南低的特征. 地处海河流域大清河水系 九河下梢的白洋淀, 承接南支潴龙河、孝义河、唐河, 西侧府河、漕河、瀑河、萍河以及北侧的白沟引河水, 并 经由苯林庄枢纽排人赵王新河,在当地具有蓄水行洪的重要作用 (图 1a).

以水文地质要素为依据, 将该地区 4 个含水层组划分为浅层地下水系统和深层地下水系统 (图 2). 浅 层地下水主要存在于第 $\mathrm{I}$ 和第 II 含水层组内, 为全新统 $(\mathrm{Qh})$ 和上更新统 $\left(\mathrm{Qp}_{3}\right)$ 含水层. 第 $\mathrm{I}$ 、II 含水层组属 


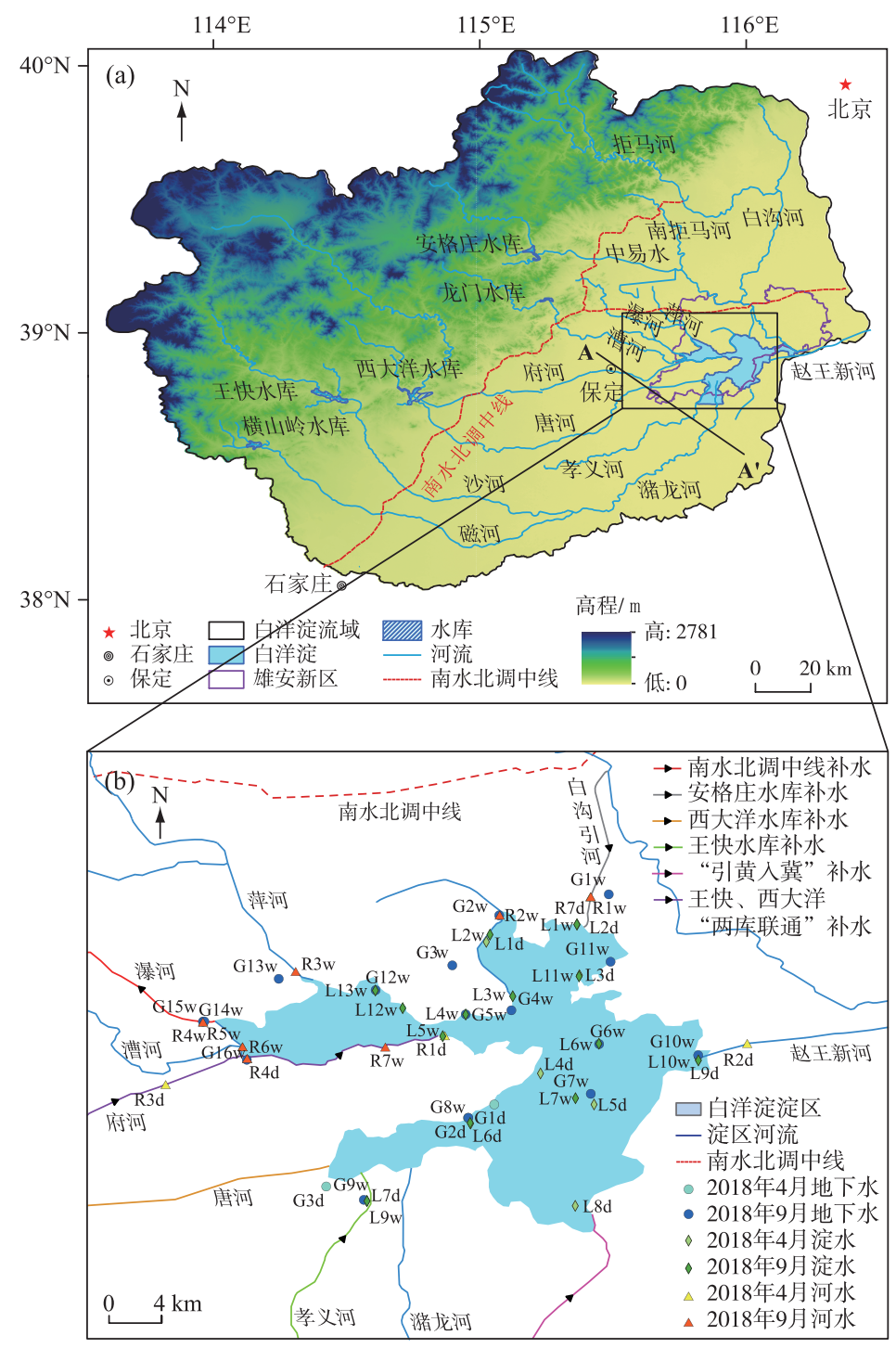

图 1 白洋淀流域水系 (a) 及淀区补水线路、采样点分布 $(\mathrm{b})$

Fig.1 River system of Lake Baiyangdian(a), hydrating line and distribution of sampling sites(b)

潜水和浅层承压水, 水位埋深为 $5 \sim 20 \mathrm{~m}$, 含水层厚度小于 $40 \mathrm{~m}$, 底界深度为 $150 \sim 180 \mathrm{~m}$, 以中、细、粉砂为主. 浅层地下水受大气降水、农业灌溉、地表水人渗及侧向径流补给. 深层地下水主要赋存于第 III 和第 IV 含水层 组内, 为中更新统 $\left(Q p_{2}\right)$ 和下更新统 $\left(Q p_{1}\right)$ 含水层. 第 III 和第 IV 含水层组主要为承压水, 水位埋深为 $25 \sim 35$ $\mathrm{m}$, 含水层厚度为 $100 \sim 180 \mathrm{~m}$, 低界深度为 $350 \sim 600 \mathrm{~m}$, 岩性以粗、中、细砂为主, 主要受侧向径流补给 ${ }^{[29]}$.

1960 年以来, 受气候变化与人类活动的影响, 人淀水量逐年减少, 除白沟引河、府河及孝义河外的大部 分人淀河流基本断流, 白洋淀由天然过水型湖泊逐渐变为人工调蓄型湖泊 ${ }^{[30]}$. 与此同时,水位下降、水体污 染、湿地萎缩、淀区沼泽化以及生物多样性退化等一系列问题亟待解决. 2017 年雄安新区建立, 作为区域生 态屏障, 白洋淀在雄安新区建设中有 “以淀兴城、城淀共荣” 的作用. 为保障区域生态水源, 1981-2018 年政 府相继采取了上游水库补水 (王快水库、西大洋水库、安格庄水库、岳城水库)、“引黄济淀”、“引岳济淀”、 “南水北调” 中线工程补水等一系列措施 (图 3). 上游水库补水及跨流域调水的多水源补水措施,使白洋淀 淀区水质逐步优化, 湿地面积增加, 区域水环境得到进一步改善, 遏制了白洋淀生态环境的进一步退化. 
补水线路如图 $1 \mathrm{~b}$ 所示. 王快水库水流经沙河总干渠、月明河、孝义河向白洋淀补水;西大洋水库水通过 唐河总干渠流至白洋淀; 安格庄水库由中易水、南拒马河、白沟引河向白洋淀补水. 2004 年 3 月 1 日至 6 月 29 日 “引岳济淀” 工程以岳城水库为起点, 利用㵚阳河、老漳河、滏东排河、小白河等现有河渠向白洋淀补水 $1.59 \times 10^{8} \mathrm{~m}^{3[31]}$. 2006- 2011 年自 “引黄济淀” 工程向白洋淀补水 5 次, 从黄河位山闸引水,经位山三干渠、穿 卫工程, 沿清临干渠、清凉江、滏东排河、小白河、人文干渠进人淀区, 补水量为 $4.52 \times 10^{8} \mathrm{~m}^{3[27]} .2012$ 年 5 月 30 日, “两库 (王快水库一西大洋水库) 连通”工程竣工, 王快水库水跨沙河流域至唐河流域, 经三会河流人西 大洋水库, 再经保定市区“大水系输水”工程, 由白洋淀应急输水工程及府河向白洋淀补水. 2017 年 11 月 16 日“引黄人冀”补淀工程自卫河、老漳河、㵚东排河、澽沱河、古洋河、小白河和任文干渠输水至白洋淀. 2018 年 4 月 16 日 “南水北调” 中线工程首次通过瀑河退水闸、北易水退水闸、郑家佐分水口, 向白洋淀上游河道 及淀区补水, 人淀水量达 $1 \times 10^{8} \mathrm{~m}^{3}$.

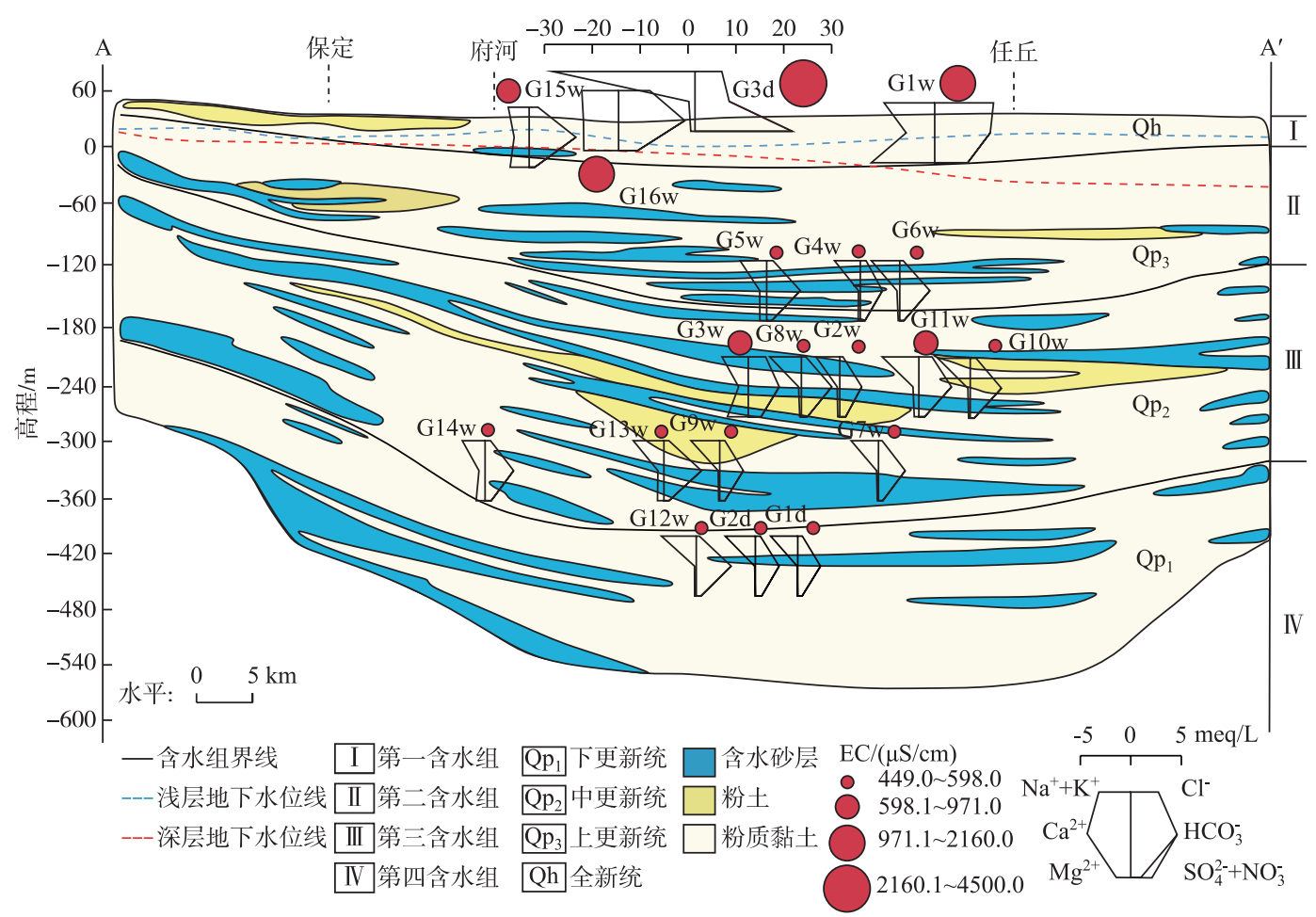

图 2 研究区水文地质剖面 ${ }^{[29]}$ 及地下水水化学组成

Fig.2 Hydrogeology profile in the study area ${ }^{[29]}$ and hydrochemistry of groundwater

\section{2 材料与方法}

\section{1 样品采集与测试}

为分析 2018 年生态补水前、后白洋淀湿地各水体的水化学特征, 于 2018 年 4 月 (补水前) 和 9 月 (补水 后) 采集 55 组水样, 采样点分布见图 1b. 4 月采集地下水水样 3 组 ( G1d G3d), 其中 G3d 为浅层地下水, 淀 水 9 组 $(\mathrm{L} 1 \mathrm{~d} \sim \mathrm{L} 9 \mathrm{~d})$, 河水 7 组 ( R1d R7d) ; 9 月采集地下水水样 16 组 ( G1w G16w), 其中 $\mathrm{G} 1 \mathrm{w} 、 \mathrm{G} 15 \mathrm{w} 、 \mathrm{G} 16 \mathrm{w}$ 为浅层地下水, 淀水 13 组 $(\mathrm{L} 1 \mathrm{w} \sim \mathrm{L} 13 \mathrm{w})$, 河水 7 组 $(\mathrm{R} 1 \mathrm{w} \sim \mathrm{R} 7 \mathrm{w})$. 地下水采自于周围居民灌溉及生活用水水 井, 采样时调查地下水采样点处的水井井深和成井情况. 用水样润洗采样瓶后取样, 现场测定采样点经纬 度、水体电导率 $(\mathrm{EC})$ 、水温 $(\mathrm{T})$ 和 $\mathrm{pH}$ (Multi 3430, WTW). 在天津师范大学天津市水环境与水资源重点实验 室测试水化学组成. 水样经 $0.2 \mu \mathrm{m}$ 水系滤膜过滤后, 运用电感耦合等离子体发射光谱仪 (ICP-OES, Perkin- 
Elmer Optima 8300DV) 测定主要阳离子 $\left(\mathrm{Ca}^{2+} 、\right.$ $\left.\mathrm{Mg}^{2+} 、 \mathrm{Na}^{+} 、 \mathrm{~K}^{+}\right)$浓度, 检测限为 $1 \mu \mathrm{g} / \mathrm{L}$; 阴离子 $\mathrm{SO}_{4}^{2-} 、 \mathrm{Cl}^{-} 、 \mathrm{NO}_{3}^{-}$浓度由离子色谱仪( ICS-600, Dionex ) 测定, 检测限为 $0.01 \mathrm{mg} / \mathrm{L}$, 测定精度为 $1 \%$. 采用稀硫酸一甲基橙滴定法测定 $\mathrm{HCO}_{3}^{-}$浓 度,在取样后 $24 \mathrm{~h}$ 内移取 $50 \mathrm{~mL}$ 待测水样,加人 浓度为 $1 \%$ 的甲基橙指示剂,用标准浓度稀硫酸 滴定,精度为 $1 \%$.

\section{2 数据分析}

对各离子浓度进行描述性统计分析,运用 ArcGIS 软件绘制白洋淀流域水系、淀区补水线 路、采样点分布及水体 EC 值图; 用 Microsoft Excel 软件绘制 Stiff 图,水文地质剖面图采用

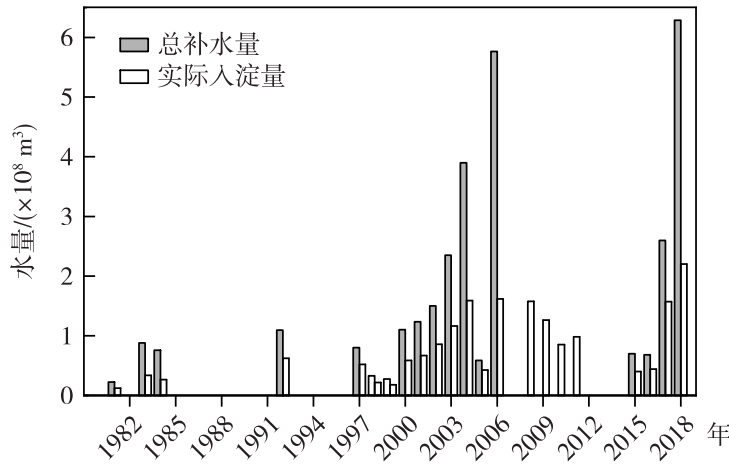

图 3 白洋淀生态补水信息

Fig.3 Information of ecological water replenishment to the Lake Baiyangdian CorelDRAW 软件绘制. 利用 AquaChem 软件制作

Piper 图以分析水体水化学类型. 为明晰水体离子来源,应用 Origin 软件绘制 Gibbs 模型图.

\section{3 结果与分析}

\section{1 水化学特征}

补水后白洋淀各水体 EC 均值减小 (表 1). 淀区地表水水体 EC 值呈现 “南高北低” 的空间特征, 浅层地 下水 $\mathrm{EC}$ 值变异性较大, 深层地下水 $\mathrm{EC}$ 值相对稳定. 研究区水体 $\mathrm{EC}$ 均值为 $1097.87 \mu \mathrm{S} / \mathrm{cm}$, 地下水、淀水和 河水的 $\mathrm{EC}$ 值范围分别为 449 4500、626 2570 和 704 $2630 \mu \mathrm{S} / \mathrm{cm}$. 补水前水体 $\mathrm{EC}$ 均值为 $1493.2 \mu \mathrm{S} / \mathrm{cm}$, 补水后降至 $889.2 \mu \mathrm{S} / \mathrm{cm}$. 河水 $\mathrm{EC}$ 值空间变幅较大, 补水前位于白洋淀下游的赵王新河水体 $\mathrm{EC}$ 值高达 $2630 \mu \mathrm{S} / \mathrm{cm}$, 补水后 $\mathrm{EC}$ 最大值位于孝义河人淀口 ( $\mathrm{L} 9 \mathrm{w}$ ), 为 $2570 \mu \mathrm{S} / \mathrm{cm}$. 补给来源的多样性使得井深为 20 $200 \mathrm{~m}$ 的浅层地下水 $\mathrm{EC}$ 值变异较大, 而井深 $>400 \mathrm{~m}$ 的深层地下水 $\mathrm{EC}$ 值相对稳定 (图 2). 位于瀑河附 近的 $\mathrm{G} 14 \mathrm{w}(400 \mathrm{~m})$ 和 $\mathrm{G} 15 \mathrm{w}(100 \mathrm{~m})$ 处于同一地点, 但由于井深不同, EC 值分别为 557 和 $739 \mu \mathrm{S} / \mathrm{cm}$, 表明了 浅层与深层地下水中间存在不透水层, 分属于不同含水层. 浅层地下水由于受到人类活动影响水体矿化度

表 12018 年各水体补水前后水化学指标

Tab.1 Physicochemical parameters of water samples before and after ecological water replenishment in 2018

\begin{tabular}{|c|c|c|c|c|c|c|c|c|c|c|c|c|}
\hline \multirow{2}{*}{ 水体 } & \multirow{2}{*}{ 项目 } & \multirow{2}{*}{ 时期 } & \multirow{2}{*}{$\begin{array}{c}\mathrm{EC} / \\
(\mu \mathrm{S} / \mathrm{cm})\end{array}$} & \multirow{2}{*}{$\mathrm{pH}$} & \multicolumn{8}{|c|}{ 水化学组成 $/(\mathrm{mg} / \mathrm{L})$} \\
\hline & & & & & $\mathrm{Ca}^{2+}$ & $\mathrm{Mg}^{2+}$ & $\mathrm{Na}^{+}$ & $\mathrm{K}^{+}$ & $\mathrm{HCO}_{3}^{-}$ & $\mathrm{SO}_{4}^{2-}$ & $\mathrm{Cl}^{-}$ & $\mathrm{NO}_{3}^{-}$ \\
\hline \multirow[t]{4}{*}{ 地下水 } & 均值 & 补水前 & 1834.7 & 8.6 & 10.0 & 3.7 & 298.5 & 0.3 & 248.3 & 351.6 & 84.4 & 4.3 \\
\hline & & 补水后 & 745.9 & 8.1 & 26.3 & 21.7 & 111.1 & 1.2 & 283.4 & 55.2 & 64.4 & 10.8 \\
\hline & 标准差 & 补水前 & 2308.4 & 1.1 & 13.6 & 6.0 & 333.6 & 0.2 & 100.5 & 541.2 & 99.2 & - \\
\hline & & 补水后 & 466.7 & 0.7 & 32.1 & 32.9 & 26.6 & 1.0 & 99.3 & 54.3 & 83.3 & 9.8 \\
\hline \multirow[t]{4}{*}{ 淀水 } & 均值 & 补水前 & 1526.1 & 8.3 & 14.7 & 2.8 & 203.8 & 4.2 & 111.9 & 142.5 & 181.3 & 8.4 \\
\hline & & 补水后 & 1055.8 & 7.8 & 51.1 & 30.7 & 133.9 & 10.4 & 338.7 & 89.9 & 121.7 & 9.6 \\
\hline & 标准差 & 补水前 & 386.6 & 1.3 & 3.0 & 1.0 & 94.7 & 1.1 & 79.4 & 65.8 & 60.1 & 1.3 \\
\hline & & 补水后 & 495.4 & 0.3 & 10.2 & 8.3 & 138.6 & 6.5 & 141.4 & 66.3 & 68.4 & 6.1 \\
\hline \multirow[t]{4}{*}{ 河水 } & 均值 & 补水前 & 1304.6 & 8.7 & 19.6 & 2.3 & 135.5 & 4.7 & 76.5 & 118.4 & 115.7 & 17.1 \\
\hline & & 补水后 & 907.4 & 7.7 & 55.9 & 27.6 & 88.5 & 9.0 & 259.6 & 62.5 & 100.4 & 23.2 \\
\hline & 标准差 & 补水前 & 608.8 & 1.0 & 4.1 & 1.6 & 83.9 & 1.9 & 33.6 & 119.9 & 68.9 & 5.1 \\
\hline & & 补水后 & 138.6 & 0.5 & 13.5 & 9.9 & 30.6 & 2.9 & 60.0 & 22.9 & 53.3 & 13.8 \\
\hline
\end{tabular}

“一”表示未检出. 
较大,位于唐河人淀口的 G3d (井深为 $20 \mathrm{~m}$ ) EC 值高达 $4500 \mu \mathrm{S} / \mathrm{cm}$.

白洋淀水体的主要阳离子为 $\mathrm{Na}^{+}$, 占阳离子浓度的 $68 \%$, 其次为 $\mathrm{Ca}^{2+} 、 \mathrm{Mg}^{2+}$; 补水前阴离子中为 $\mathrm{SO}_{4}^{2-}$ 和 $\mathrm{Cl}^{-}$浓度较高, 补水后水体主要阴离子变为 $\mathrm{HCO}_{3}^{-}$. 补水后 $\mathrm{Na}^{+}$浓度减小, $\mathrm{Ca}^{2+} 、 \mathrm{Mg}^{2+} 、 \mathrm{~K}^{+} 、 \mathrm{HCO}_{3}^{-}$和 $\mathrm{NO}_{3}^{-}$浓度均 值均增加. 地下水、淀水与河水的 $\mathrm{Ca}^{2+} 、 \mathrm{Mg}^{2+}$ 浓度分别为补水前的 2.63、3.47、2.85 倍(表 1). 补水前各水体主 要阴离子为 $\mathrm{SO}_{4}^{2-}$. 地下水 $\mathrm{SO}_{4}^{2-}$ 变异系数高达 1.54 , 浅层地下水 $\mathrm{SO}_{4}^{2-}$ 浓度约为深层地下水的 9 倍. 补水后 $\mathrm{HCO}_{3}^{-}$为主要阴离子, 淀水 $\mathrm{HCO}_{3}^{-}$浓度高达 $338.7 \mathrm{mg} / \mathrm{L} . \mathrm{NO}_{3}^{-}$浓度时空变异性较大, 河水 $\mathrm{NO}_{3}^{-}$浓度显著大于其 他水体的 $\mathrm{NO}_{3}^{-}$浓度,其中府河 $\mathrm{NO}_{3}^{-}$浓度高达 $35.3 \mathrm{mg} / \mathrm{L}$, 深层地下水 $\mathrm{G} 3 \mathrm{w}$ 与 $\mathrm{G} 11 \mathrm{w}$ 的 $\mathrm{Cl}^{-}$浓度较高.

\section{2 水化学类型}

地表水水化学类型时空变异性较大. 补水前淀水水化学类型主要为 $\mathrm{Na}-\mathrm{Cl} \cdot \mathrm{SO}_{4} 、 \mathrm{Na}-\mathrm{Cl} \cdot \mathrm{HCO}_{3}$, 补水后淀 水水化学类型种类繁多, 主要为 $\mathrm{Na} \cdot \mathrm{Mg}-\mathrm{HCO}_{3} \cdot \mathrm{Cl} 、 \mathrm{Na} \cdot \mathrm{Ca}-\mathrm{HCO}_{3} \cdot \mathrm{Cl} 、 \mathrm{Ca} \cdot \mathrm{Na}-\mathrm{HCO}_{3} \cdot \mathrm{Cl} 、 \mathrm{Ca} \cdot \mathrm{Mg}-\mathrm{HCO}_{3} \cdot \mathrm{SO}_{4}$. 补水 前后河水水化学类型差异较大. 补水前府河沿程流向水化学类型为: $\mathrm{Na}-\mathrm{Cl} \cdot \mathrm{SO}_{4} 、 \mathrm{Na}-\mathrm{Cl} \cdot \mathrm{HCO}_{3} 、 \mathrm{Na}-\mathrm{Cl}$, 瀑河水 化学类型为 $\mathrm{Na}-\mathrm{HCO}_{3} \cdot \mathrm{Cl}$, 白沟引河河水化学类型为 $\mathrm{Na}-\mathrm{Cl} \cdot \mathrm{SO}_{4}$, 赵王新河水化学类型为 $\mathrm{Na}-\mathrm{SO}_{4} \cdot \mathrm{Cl}$; 补水后 府河、瀑河、白沟引河以及南河干渠的水化学类型分别为 $\mathrm{Na} \cdot \mathrm{Ca}-\mathrm{Cl} \cdot \mathrm{HCO}_{3} 、 \mathrm{Mg} \cdot \mathrm{Ca}-\mathrm{HCO}_{3} 、 \mathrm{Ca} \cdot \mathrm{Mg}-\mathrm{HCO}_{3} \cdot \mathrm{SO}_{4}$ 和 $\mathrm{Na} \cdot \mathrm{Ca}-\mathrm{HCO}_{3}$.

补水前后深层地下水水化学类型较稳定,浅层地下水水化学类型变化较复杂. 淀区及周边深层地下水 水化学类型以 $\mathrm{Na}-\mathrm{HCO}_{3}$ 为主, 补水后小部分深层地下水水化学类型发生改变. 位于瀑河周边的深层地下水 $\mathrm{G} 14 \mathrm{w}$ 水化学类型为 $\mathrm{Na} \cdot \mathrm{Mg}-\mathrm{HCO}_{3}, \mathrm{G} 3 \mathrm{w}$ 水化学类型为 $\mathrm{Na} \cdot \mathrm{Mg}-\mathrm{HCO}_{3} \cdot \mathrm{Cl}, \mathrm{G} 11 \mathrm{w}$ 水化学类型为 $\mathrm{Na}-\mathrm{HCO}_{3} \cdot \mathrm{Cl}$. 浅 层地下水水化学类型变化显著. 补水前位于唐河附近的浅层地下水水化学类型为 $\mathrm{Na}_{-} \mathrm{SO}_{4}$, 补水后浅层地下 水水化学类型为 $\mathrm{Na} \cdot \mathrm{Ca}-\mathrm{HCO}_{3} \cdot \mathrm{Cl} 、 \mathrm{Na} \cdot \mathrm{Mg}-\mathrm{HCO}_{3} 、 \mathrm{Mg} \cdot \mathrm{Na}-\mathrm{Cl} \cdot \mathrm{HCO}_{3}$.

位于瀑河人淀口的深层地下水 $\mathrm{G} 14 \mathrm{w}(400 \mathrm{~m})$ 与浅层地下水 $\mathrm{G} 15 \mathrm{w}(100 \mathrm{~m})$ 的水化学类型在瀑河河水采 样点 $R 4 \mathrm{w}$ 与 $\mathrm{R} 6 \mathrm{~d}$ 之间, 且浅层地下水 $\mathrm{G} 15 \mathrm{w}(100 \mathrm{~m})$ 水化学类型更接近于补水后瀑河水水化学类型 $\mathrm{R} 4 \mathrm{w}$; 位 于白沟引河人淀口的地下水 $\mathrm{G} 1 \mathrm{w}(100 \mathrm{~m})$ 水化学类型在 $\mathrm{R} 1 \mathrm{w}$ 与 $\mathrm{R} 7 \mathrm{~d}$ 之间且与 $\mathrm{R} 1 \mathrm{w}$ 水化学类型基本一致; 府 河人淀口的地下水 $\mathrm{G} 16 \mathrm{w}(50 \mathrm{~m})$ 水化学类型为 $\mathrm{Na} \cdot \mathrm{Ca}-\mathrm{HCO}_{3} \cdot \mathrm{Cl}$ 与府河河水 $\mathrm{R} 6 \mathrm{w}$ 水化学类型 $\mathrm{Na} \cdot \mathrm{Ca}-\mathrm{Cl}$ $\mathrm{HCO}_{3}$ 较为接近; 地表水 $(\mathrm{R} 1 \mathrm{w} 、 \mathrm{R} 4 \mathrm{w} 、 \mathrm{R} 6 \mathrm{w})$ 与其附近的浅层地下水 $(\mathrm{G} 1 \mathrm{w} 、 \mathrm{G} 15 \mathrm{w} 、 \mathrm{G} 16 \mathrm{w})$ 水化学类型类似. 这些 现象都表明白洋淀地表水与浅层地下水存在密切的水力联系, 而深层地下水与浅层地下水水力联系较弱. 补水后地表水与地下水水化学类型位于补水前地表水、太行山区地下水及水库水水化学类型之间 (图 4), 表 明补水改变了白洋淀水体水化学类型,且地下水受地表水、太行山区侧向径流的共同补给.

\section{3 水化学组分影响因素}

Gibbs 图是分析水化学成分主控作用的一种重要方法, 通过探究矿化度与 $\mathrm{Na}^{+} /\left(\mathrm{Na}^{+}+\mathrm{Ca}^{2+}\right) 、 \mathrm{Cl}^{-} /\left(\mathrm{Cl}^{-}+\right.$ $\mathrm{HCO}_{3}^{-}$) 的关系, 可以反映出水体中各离子的起源机制 (大气降水、岩石风化、蒸发结晶) 及其变化趋势. 由图 5 可知, 白洋淀湿地水体矿化度中等, $\mathrm{Na}^{+} /\left(\mathrm{Na}^{+}+\mathrm{Ca}^{2+}\right)$ 比值数据点大部分位于 $0.4 \sim 1$ 的范围内, $\mathrm{Cl}^{-} /\left(\mathrm{Cl}^{-}+\right.$ $\mathrm{HCO}_{3}^{-}$) 比值数据点分布较为分散, 部分样点落在 Gibbs 分布模型外, 说明不同时期水体离子来源除受岩石风 化与蒸发结晶作用影响外还受人类活动等因素的影响.

补水前水体的水化学组成主要受控于岩石风化、蒸发结晶作用,补水后受岩石风化作用影响较大. 补水 前地下水 TDS 浓度均值为 $874 \mathrm{mg} / \mathrm{L}, \mathrm{Na}^{+} /\left(\mathrm{Na}^{+}+\mathrm{Ca}^{2+}\right)$ 比值位于 $0.8 \sim 1$ 之间, $\mathrm{Cl}^{-} /\left(\mathrm{Cl}^{-}+\mathrm{HCO}_{3}^{-}\right)$均值为 0.2 , 其 中浅层地下水 $\mathrm{G} 3 \mathrm{~d}(20 \mathrm{~m}) \mathrm{Cl}^{-} /\left(\mathrm{Cl}^{-}+\mathrm{HCO}_{3}^{-}\right)$比值最高, 为 0.35 , TDS 值为 $2078.0 \mathrm{mg} / \mathrm{L}$, 表明该采样点受蒸发 结晶作用影响较大. 补水后地下水 TDS 浓度均值为 $432.4 \mathrm{mg} / \mathrm{L}, \mathrm{Na}^{+} /\left(\mathrm{Na}^{+}+\mathrm{Ca}^{2+}\right)$ 比值位于 $0.5 \sim 1$ 之间, $\mathrm{Cl}^{-} /$ $\left(\mathrm{Cl}^{-}+\mathrm{HCO}_{3}^{-}\right)$均值为 0.15 , 数据点具有向岩石风化作用方向偏移的趋势. 补水后深层地下水 $\mathrm{Na}^{+} /\left(\mathrm{Na}^{+}+\right.$ $\left.\mathrm{Ca}^{2+}\right)$ 稍有减小, 浅层地下水 $(\mathrm{G} 1 \mathrm{w} 、 \mathrm{G} 16 、 \mathrm{G} 15 \mathrm{w}) \mathrm{Na}^{+} /\left(\mathrm{Na}^{+}+\mathrm{Ca}^{2+}\right)$ 显著减小, 表明该时期地下水 $\mathrm{Ca}^{2+}$ 浓度较高. 补水前地表水 $\mathrm{Na}^{+} /\left(\mathrm{Na}^{+}+\mathrm{Ca}^{2+}\right)$ 比值大于 $0.8, \mathrm{Cl}^{-} /\left(\mathrm{Cl}^{-}+\mathrm{HCO}_{3}^{-}\right)$比值大于 0.5 , 补水后明显减小, 表明受岩石 风化作用影响更为强烈, 且 $\mathrm{Ca}^{2+} 、 \mathrm{HCO}_{3}^{-}$浓度增加. 


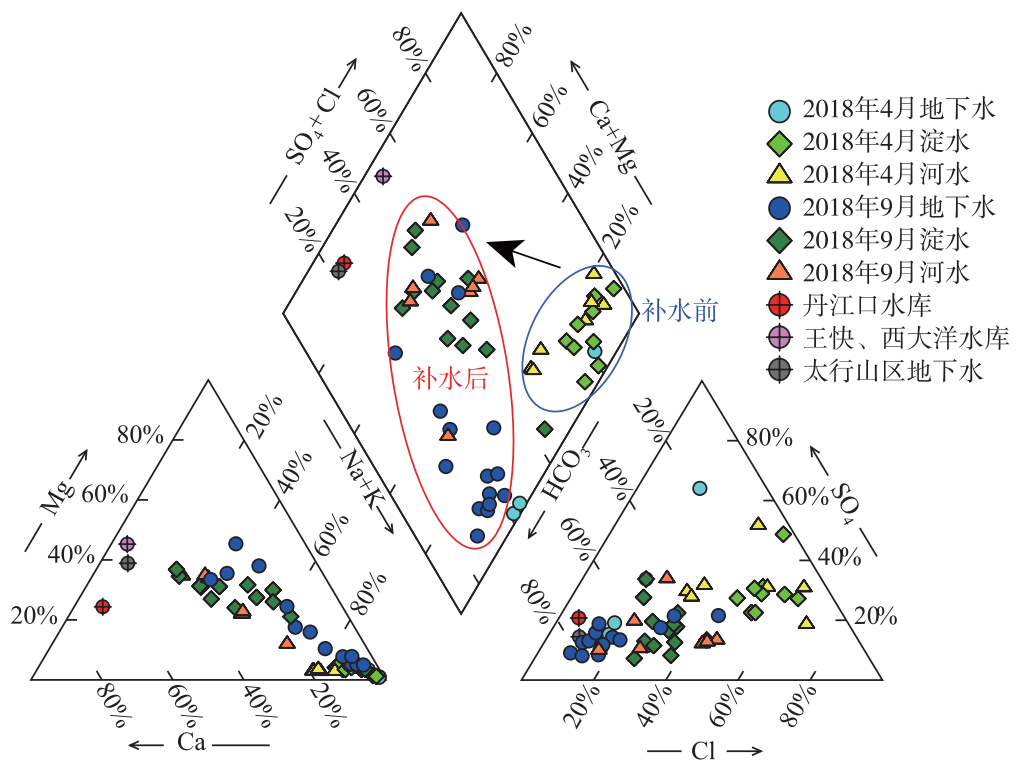

图 4 白洋淀不同时期各水体 Piper 图

Fig.4 Piper plots of different waters of Lake Baiyangdian in different periods
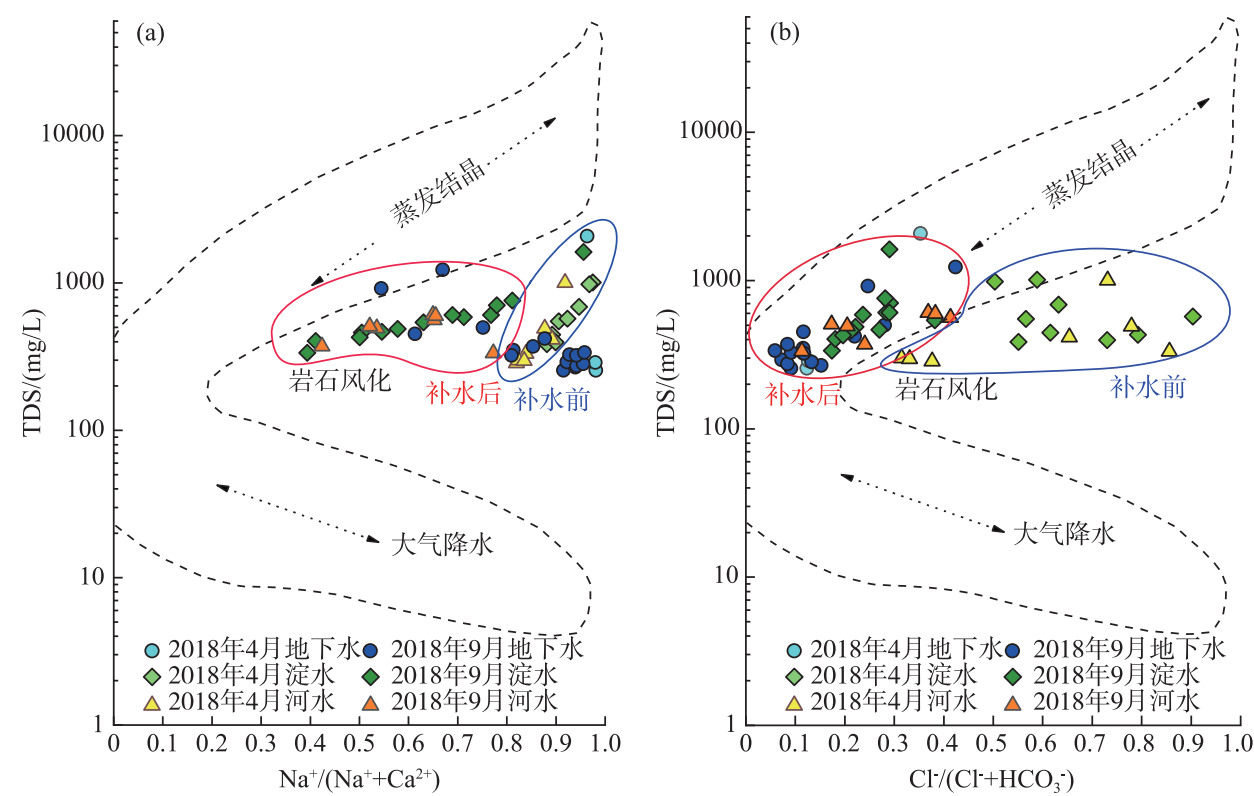

图 5 白洋淀湿地不同时期各水体 Gibbs 图

Fig.5 Gibbs diagram of different waters of Lake Baiyangdian in different periods

\section{4 讨论}

\section{1 生态补水对地表水环境的影响}

生态补水增加了人淀水量, 使淀区水位上升, 水面积扩大, 水质得到一定改善. 1965 年前, 白洋淀主要由 
降水补给, 水量丰富, 1957 年水位高达 $9.5 \mathrm{~m} ; 1965$ 年后, 上游水库的修建及区域用水量的增加, 导致人淀水 量减少, 1983-1988 年出现连续 5 年干淀的现象 ${ }^{[20]}, 1990-2000$ 年, 白洋淀水质呈下降趋势 ${ }^{[23]}$. 为化解干

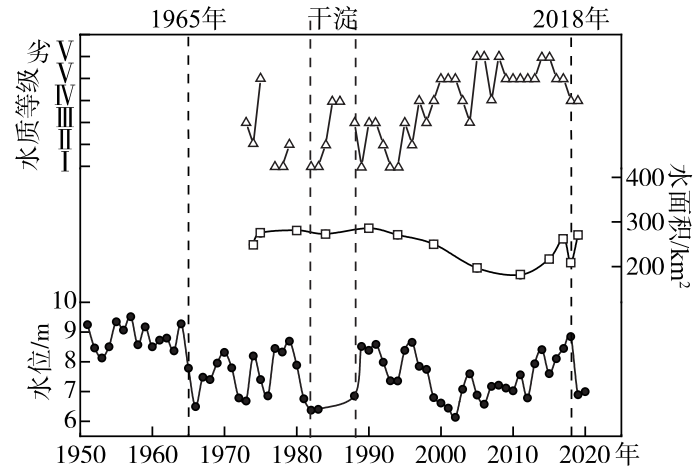

图 $61950-2020$ 年白洋淀水位、 水面积与水质等级 ${ }^{[21,23]}$

Fig.6 Water level, water area and water quality grade from 1950 to $2020^{[21,23]}$ in Lake Baiyangdian 淀危机,改善淀区水质,遏制白洋淀生态退化,政府 多次采取生态补水及淀区污染治理措施. 19881996 年,白洋淀水位大幅度上升, 2007 年后水质状 况明显改善(图 6). 但在补水过程中仍旧存在诸多 问题, 如: 河道渗漏蒸发, 沿岸居民及工厂非法取 水、排放污染物, 引水工程存在安全隐患且缺乏较 为完善的长效补水机制 ${ }^{[32]}$. 1997-2002 年白洋淀 水位持续下降, 2000-2008 年再次出现干淀现象, 白洋淀“水危机”并没有从根本上得到解决.

2018 年 4 月发布的《河北雄安新区规划纲要》 明确指出, “建立多水源补水机制, 坚持控源一截 污一治河系统治理”. 通过改进补水方案、整治排污 企业、优化淀中村废水处理体系以及规范水产养 殖, 淀区水环境好转, 水质逐步优化 ${ }^{[33]}$. 截至 2019 年底, 淀区水位始终保持在 $6.5 \mathrm{~m}$ 以上, 水面积增长 至约 $250 \mathrm{~km}^{2[34]}$ (图 6). 2019 年颁布的《白洋淀生态 环境治理和保护规划 (2018-2035 年)》提出: 到 2022 年,淀区生态环境质量将初步恢复, 2035 年综合治理 全面完成, 淀区水位将维持在 $6.5 \sim 7 \mathrm{~m}$, 面积将扩大至 $360 \mathrm{~km}^{2}$, 水质将达到国家地表水环境质量 III IV 类标 准 ${ }^{[34]}$. 白洋淀将逐步恢复其“华北之肾”的功能,维护雄安新区乃至华北平原的生态平衡.

生态补水改变了地表水水化学特征. 南水北调中线工程水源地 (丹江口水库)、安格庄水库、西大洋水 库、王快水库水体主要阳离子均为 $\mathrm{Ca}^{2+}$ 和 $\mathrm{Mg}^{2+}$, 主要阴离子为 $\mathrm{HCO}_{3}^{-[35-36]} .2018$ 年 4-6 月通过南水北调中线 工程及各水库向白洋淀补水 $1.8 \times 10^{8} \mathrm{~m}^{3}$, 短期内水量急增. 水体混合及稀释作用导致淀区地表水 $\mathrm{HCO}_{3}^{-}$浓度 显著增加, $\mathrm{Ca}^{2+} 、 \mathrm{Mg}^{2+}$ 浓度也有小幅度提升, $\mathrm{Na}^{+} 、 \mathrm{Cl}^{-}$和 $\mathrm{SO}_{4}^{2-}$ 浓度下降(图 7). 华北平原年均蒸发量较大, 白洋 淀地区蒸发量最高可达 $2132.6 \mathrm{~mm}^{[29]}$, 多水源长距离补水使地表水在调配过程中受强烈蒸发作用的影响, 也会导致地表水离子浓度增加. 2010 年枯水期淀水 $\mathrm{NO}_{3}^{-}$浓度为 $24.80 \mathrm{mg} / \mathrm{L}^{[37]}, 2018$ 年枯水期 $\mathrm{NO}_{3}^{-}$浓度下降 至 $8.4 \mathrm{mg} / \mathrm{L}$ (表 1), 表明近年来淀区水环境有所好转. 但依旧存在人淀河流水质较差, $\mathrm{TN} 、 \mathrm{TP}$ 浓度高的问 题 ${ }^{[7]}$. 补水过程中, 沿途居民生活污水和农田地表径流中的硝酸盐进人淀区 ${ }^{[12]}$, 导致补水后淀水与河水 $\mathrm{NO}_{3}^{-}$浓度增加 (表 1). 所以在生态补水前应 “先治污, 后补水”, 加强对生活污水无序排放、养殖污染以及农 业面源污染等方面的综合治理,改善区域地表水水质.

\section{2 生态补水对地下水环境的影响}

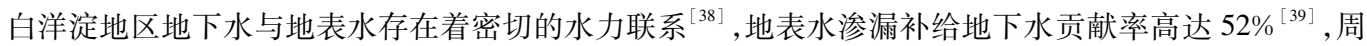
边地区浅层地下水平均更新速率为 $4.4 \% / \mathrm{a}^{[40]}$. 近几十年来, 随着经济社会的发展, 区域用水量不断增加, 白 洋淀地下水超采现象严重,地下水位大幅下降. 1974-2007 年, 白洋淀流域地下水埋深以平均每年 $0.51 \mathrm{~m}$ 的速率下降, 在淀区附近形成地下水降落漏斗群 ${ }^{[41]}$. 在 2000 年后, 随着补水量不断加大, 淀区周边地下水 资源涵养修复效果显著,地下水降落漏斗群面积减小,水位有所上 升 $^{[14,42]}$. 2015-2018 年间,白洋淀流域大 部分地区地下水储量呈上升趋势 ${ }^{[43]}$. 预计到 2030 年, 白洋淀地区浅层地下水位将较 2016 年上升 $20 \sim 30 \mathrm{~m}$, 淀区南部或将上升 $35 \mathrm{~m}^{[44]}$.

生态补水改变了浅层地下水的水化学特征, 对深层地下水影响较小. 补水后, 浅层地下水离子浓度变化 与地表水离子浓度变化保持一致, $\mathrm{HCO}_{3}^{-} 、 \mathrm{Ca}^{2+} 、 \mathrm{Mg}^{2+}$ 和 $\mathrm{NO}_{3}^{-}$浓度均有不同程度的提升 (图 3、表 2). 深层地下 水除 $\mathrm{HCO}_{3}^{-}$和 $\mathrm{NO}_{3}^{-}$浓度有小幅度增加外,其余离子浓度基本保持不变 (图 3、表 2). 地下水 $\mathrm{NO}_{3}^{-}$浓度显著增 加, 2018 年浅层地下水 $\mathrm{NO}_{3}^{-}$浓度约为 2010 年的 9.2 倍. 生活污水的无序排放、农田施肥及点源污染是导致地 下水 $\mathrm{NO}_{3}^{-}$浓度持续增长的主要原因 ${ }^{[12]}$. 

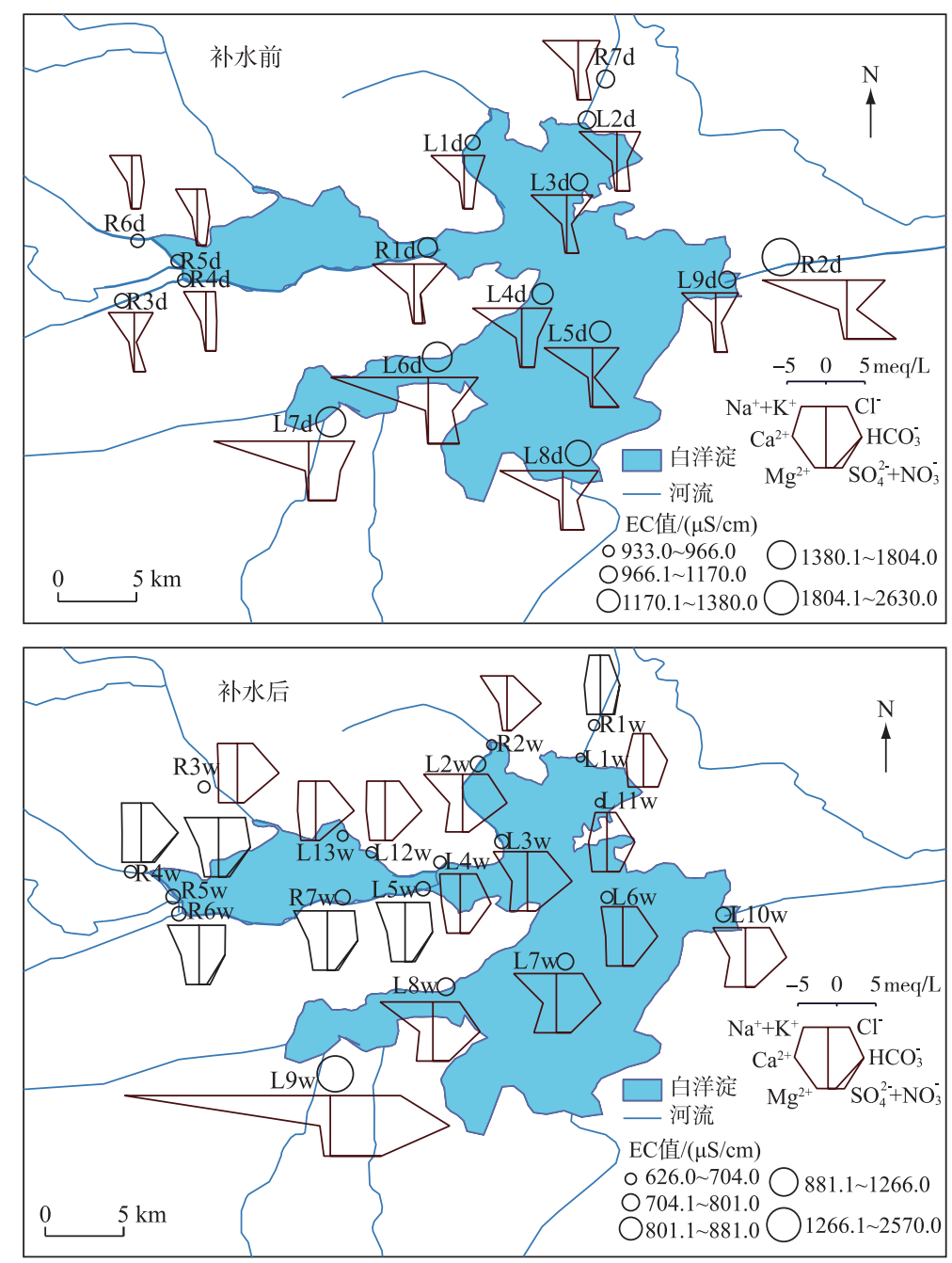

图 7 补水前、后地表水的水化学特征及 EC 值

Fig.7 The hydrochemical characteristics and EC value of surface water

before and after ecological water replenishment

2008 年白洋淀地区浅层地下水水化学类型主要为 $\mathrm{Na}-\mathrm{HCO}_{3}^{[46]}, 2010$ 年为 $\mathrm{Na}-\mathrm{HCO}_{3} \cdot \mathrm{Cl}^{[45]}, 2018$ 年 9 月浅 层地下水水化学类型向 $\mathrm{Ca} \cdot \mathrm{Mg}-\mathrm{HCO}_{3}$ 型转变 (图 5). 预计到 2030 年, 生态补水使地下水水位上升, 白云石等矿 物溶解将会减少 ${ }^{[44]}$. 因岩盐溶解和阳离子交替吸附作用, 导致富含 $\mathrm{Ca}^{2+}$ 及 $\mathrm{Mg}^{2+}$ 的地下水置换出岩土所吸附的 $\mathrm{Na}^{+}$, 使水体 $\mathrm{Ca}^{2+}$ 及 $\mathrm{Mg}^{2+}$ 浓度大幅下降, $\mathrm{Na}^{+}$及 $\mathrm{Cl}^{-}$浓度增加. 白洋淀地区水化学类型将变为 $\mathrm{Na}-\mathrm{HCO}_{3} \cdot \mathrm{Cl}$, 淀区 南部甚至出现 $\mathrm{Na}-\mathrm{Cl}$ 型水 ${ }^{[4]}$. 随着白洋淀补水力度的加强, 应关注地下水位上升过程中的阳离子交换及水 岩相互作用可能产生的环境问题.

\section{5 结论}

采集 2018 年白洋淀枯、丰水期 (补水前、补水后) 地表水与地下水水样,分析水体水化学组成, 主要结 论为:

1) 白洋淀地表水与浅层地下水水力联系密切, 且时空变异较大. 补水前 $\mathrm{Na}^{+}$为主要阳离子, $\mathrm{SO}_{4}^{2-}$ 和 $\mathrm{Cl}^{-}$ 
表 2 浅层地下水与深层地下水不同时期水化学指标

Tab.2 Physicochemical parameters of water samples in the surface and deep groundwater

\begin{tabular}{|c|c|c|c|c|}
\hline \multirow{2}{*}{ 离子 } & \multicolumn{2}{|c|}{ 浅层地下水 $/(\mathrm{mg} / \mathrm{L})$} & \multicolumn{2}{|c|}{ 深层地下水 $/(\mathrm{mg} / \mathrm{L})$} \\
\hline & 2010 年 5 月 & 2018 年 9 月 & 2010 年 5 月 * & 2018 年 9 月 \\
\hline $\mathrm{Ca}^{2+}$ & 65.1 & 84.4 & 16.0 & 12.9 \\
\hline $\mathrm{Mg}^{2+}$ & 71.5 & 76.2 & 7.3 & 9.1 \\
\hline $\mathrm{Na}^{+}$ & 207.8 & 132.7 & 110.4 & 106.1 \\
\hline $\mathrm{K}^{+}$ & 1.9 & 0.9 & 0.0 & 1.3 \\
\hline $\mathrm{HCO}_{3}^{-}$ & 323.1 & 460.7 & 204.0 & 242.5 \\
\hline $\mathrm{SO}_{4}^{2-}$ & 171.2 & 133.7 & 46.1 & 37.1 \\
\hline $\mathrm{Cl}^{-}$ & 342.9 & 188.0 & 52.8 & 35.9 \\
\hline $\mathrm{NO}_{3}^{-}$ & 4.3 & 39.8 & 6.2 & 17.4 \\
\hline
\end{tabular}

* 2010 年 5 月 (枯水期) 数据参考文献 $[45]$.
为主要阴离子, 淀区西南部、唐河及府河人淀口处 水体电导率较高. 补水后水体电导率降低, 地表水 与浅层地下水受混合、稀释作用的影响, $\mathrm{Ca}^{2+} 、 \mathrm{Mg}^{2+}$ 和 $\mathrm{HCO}_{3}^{-}$浓度增加, 水化学类型向 $\mathrm{Ca} \cdot \mathrm{Mg}-\mathrm{HCO}_{3}$ 转变.

2) 深层地下水与浅层地下水存在不透水层, 因此受生态补水影响较小, 水化学类型以 $\mathrm{Na}-\mathrm{HCO}_{3}$ 为主. 枯水期 (补水前) 水体离子来源受蒸发结晶 作用影响较大, 丰水期 (补水后) 岩石风化作用影响 更为强烈.

3) 生态补水使白洋淀地表水与地下水位提 升, 淀区面积增大, 水质得到改善, 缓解了由水资源 缺乏引起的生态环境退化的现状. 但补水后水体 $\mathrm{NO}_{3}^{-}$浓度上升, 所以应注意“先治污,后补水”.

水化学是反映湿地水环境的重要计量指标, 本 研究主要依据 2018 年生态补水前后及 2010 年数据进行解析, 未来将融合多学科、新方法,增加监测时间、监 测点及生态监测数据, 更全面地分析生态补水后由地下水位上升、水体在含水层中发生阳离子交换和水岩 相互作用可能引发的一系列生态环境问题.

\section{6 参考文献}

[ 1 ] Erwin KL. Wetlands and global climate change: The role of wetland restoration in a changing world. Wetlands Ecology and Management, 2008, 17(1) : 71-84. DOI: 10.1007/s11273-008-9119-1.

[ 2 ] Sun GY. Development and prospect of wetland science in China. Advances in Earth Science, 2000, 15(6): 666-672. [孙 广友. 中国湿地科学的进展与展望. 地球科学进展, 2000, 15(6) : 666-672.]

[ 3 ] Herbert ER, Boon P, Burgin AJ et al. A global perspective on wetland salinization: Ecological consequences of a growing threat to freshwater wetlands. Ecosphere, 2015, 6(10): 1-43. DOI: 10.1890/ES14-00534.1.

[ 4 ] Cavicchioli R, Ripple WJ, Timmis KN et al. Scientists' warning to humanity: Microorganisms and climate change. Nature Reviews Microbiology, 2019, 17(9) : 569-586. DOI: 10.1038/s41579-019-0222-5.

[ 5 ] Xia J. Impact of water diversion project across basins on land water cycle and water security. Journal of Basic Science and Engineering, 2009, 6(6) : 831-842. [夏军. 跨流域调水及其对陆地水循环及水资源安全影响. 应用基础与工程科 学学报, 2009, 6(6): 831-842.]

[ 6 ] Han Q, Tong RZ, Sun WC et al. Anthropogenic influences on the water quality of the Baiyangdian Lake in North China over the last decade. Science of the Total Environment, 2020, 701: 134929. DOI: 10.1016/j.scitotenv.2019.134929.

[ 7 ] Zhou L, Sun WC, Han Q et al. Assessment of spatial variation in river water quality of the Baiyangdian basin (China) during environmental water release period of upstream reservoirs. Water, 2020, 12(3) : 688. DOI: 10.3390/w12030688.

[ 8 ] Bai JH, Fang JS, Huang LB et al. Landscape pattern evolution and its driving factors of Baiyangdian lake-marsh wetland system. Geographical Research, 2013, 32(9): 1634-1644. [白军红, 房静思, 黄来斌等. 白洋淀湖沼湿地系统景观格 局演变及驱动力分析. 地理研究, 2013, 32(9) : 1634-1644.]

[ 9 ] Qin S, Cui JS, Shen LN et al. The influences of eutrophication for the carbon and nitrogen sources for aquatic consumer communities-A case study in Lake Baiyangdian. J Lake Sci, 2020, 32(6) : 1657-1670. DOI: 10.18307/2020.0608. [秦 珊, 崔建升, 申立娜等. 富营养化对湖泊消费者群落碳源和氮源的影响一以白洋淀为例. 湖泊科学, 2020,32 (6) : 1657-1670.]

[10] Zhang XX, Yi YJ, Yang ZF. Nitrogen and phosphorus retention budgets of a semiarid plain basin under different human activity intensity. Science of the Total Environment, 2020, 703: 134813. DOI: 10.1016/j.scitotenv.2019.134813.

[11] Wang SQ, Tan KD, Zheng WB et al. Regional characteristics of nitrate sources and distributions in the shallow groundwater of the Lake Baiyangdian watershed. Chinese Journal of Eco-Agriculture, 2021, 29(1) : 230-240. [王仕琴, 檀康达, 郑文波等. 白洋淀流域浅层地下水硝酸盐分布及来源的区域分异特征. 中国生态农业学报, 2021, 29(1): 230-240.] 
[12] Kong XL, Wang SQ, Ding F et al. Source of nitrate in surface water and shallow groundwater around Baiyangdian Lake area based on hydrochemical and stable isotopes. Environmental Science, 2018, 39(6) : 2624-2631. DOI: 10.13227/j.hjkx. 201709149. [孔晓乐, 王仕琴, 丁飞等. 基于水化学和稳定同位素的白洋淀流域地表水和地下水硝酸盐来源. 环境 科学, 2018, 39(6): 2624-2631.]

[13] Tang CH, Yi YJ, Yang ZF et al. Planktonic indicators of trophic states for a shallow lake (Baiyangdian Lake, China). Limnologica, 2019, 78: 125712. DOI: 10.1016/j.limno.2019.125712.

[14] Long D, Yang WT, Scanlon BR et al. South-to-North Water Diversion stabilizing Beijing's groundwater levels. Nature Communications, 2020, 11(1) : 1-10. DOI: 10.1038/s41467-020-17428-6.

[15] Xiao Y, Shan Y, Li S et al. Change in groundwater resource and environment of South-to-North water recharge area of Chaobai river. Beijing Water, 2017, (4) : 5-8. DOI: 10.19671/j.1673-4637.2017.04.002. [肖颖, 单悦, 李述等. 南水北 调水源潮白河补水区地下水资源环境变化. 北京水务, 2017, (4) : 5-8.]

[16] Zeng QH, Hu P, Zhao CP et al. Influence of multi-water resource replenishment on the hydrodynamic behavior of Baiyangdian wetland. Acta Ecologica Sinica, 2020, 40(20): 7153-7164. [曾庆慧, 胡鹏, 赵翠平等. 多水源补给对白洋淀湿 地水动力的影响. 生态学报, 2020, 40(20): 7153-7164.]

[17] Liu LC, Zheng FD, Li BH et al. Experiment of groundwater quality change for simulating the South-to-North water into the Mihuaishun aquifer. Hydrogeology \& Engineering Geology, 2015, 42(4): 18-22, 55. [刘立才, 郑凡东, 李炳华等. 南 水北调水源在密怀顺水源地回灌的地下水水质变化试验. 水文地质工程地质, 2015, 42(4): 18-22, 55.]

[18] Wang M. Interaction between river water and groundwater under influences of water transfer [Dissertation]. Taiyuan: Shanxi University, 2020. [王萌. 调水影响的河水与地下水相互作用研究 [学位论文]. 太原: 山西大学, 2020.]

[19] Kong XL, Wang SQ, Liu BX et al. Effect of water diversion on hydro-chemical characteristics of surface water and groundwater in lowland area of the North China Plain: A case study of Nanpi County, Hebei Province. Chinese Journal of Eco-Agriculture, 2016, 24(8):1135-1144. [孔晓乐, 王仕琴, 刘丙霞等. 外来调水对华北低平原区地表水和地下水水化 学特征的影响一以河北省南皮县为例. 中国生态农业学报, 2016, 24(8): 1135-1144.]

[20] Li YH, Cui BS, Yang ZF. Influence of hydrological characteristic change of Baiyangdian on the ecological environment in wetland. Journal of Natural Resources, 2004, 19 (1) : 62-68. [李英华, 崔保山, 杨志峰. 白洋淀水文特征变化对湿地 生态环境的影响. 自然资源学报, 2004, 19(1): 62-68.]

[21] Zhu JF, Zhou Y, Wang SX et al. Analysis of changes of Baiyangdian wetland from 1975 to 2018 based on remote sensing. Journal of Remote Sensing, 2019, 23(5): 971-986. [ 朱金峰, 周艺, 王世新等. 1975 年一 2018 年白洋淀湿地变化分 析. 遥感学报, 2019, 23(5): 971-986.]

[22] Ji ZH, Zhang H, Zhang Y et al. Distribution, ecological risk and source identification of heavy metals in sediments from the Baiyangdian Lake, Northern China. Chemosphere, 2019, 237: 124425. DOI: 10.1016/j.chemosphere.2019.124425.

[23] Wang HH, Bai J, Liu SC et al. Spatial and temporal variations in the water quality of Baiyangdian Lake in the recent 30 years. Journal of Agro-Environment Science, 2020, 39(5): 1051-1059. [王欢欢, 白洁, 刘世存等. 白洋淀近 30 年水 质时空变化特征. 农业环境科学学报, 2020, 39(5): 1051-1059.]

[24] Yang W, Zhao YW, Liu Q et al. A systematic literature review and perspective on water-demand for ecology of Lake Baiyangdian. J Lake Sci, 2020, 32(2) : 294-308. DOI: 10.18307/2020.0202. [杨薇, 赵彦伟, 刘强等. 白洋淀生态需水: 进展及展望. 湖泊科学, 2020, 32(2): 294-308.]

[25] Yang ZF, Hu P, Zhao Y et al. Study on ecological water demand and safeguard measures of Baiyangdian Lake and the upstream rivers under the background of Xiongan New Area. Journal of China Institute of Water Resources and Hydropower Research, 2018, 6(6) : 563-570. [ 杨泽凡, 胡鹏, 赵勇等. 新区建设背景下白洋淀及人淀河流生态需水评价和保障 措施研究. 中国水利水电科学研究院学报, 2018, 6(6): 563-570.]

[26] Tang CH, Yi YJ, Yang ZF et al. Effects of ecological flow release patterns on water quality and ecological restoration of a large shallow lake. Journal of Cleaner Production, 2018, 174: 577-590. DOI: 10.1016/j.jclepro.2017.10.338.

[27] Wang WL, Wu XL, Wang ZF. Analysis of ecological benefit of Baiyangdian Lake by Yellow River Diversion. Water Resources Development and Management, 2011, 31(7): 37-39. [王文林, 吴新玲, 王占峰. 引黄济淀对白洋淀的生态效 益分析. 水利建设与管理, 2011, 31(7): 37-39.]

[28] Zhang GN, Cao XZ, Mao TJ. Ecological benefit assessment of water supplement to Baiyangdian wetland. Journal of Ecology and Rural Environment, 2013, 29(5): 605-611. [张赶年, 曹学章, 毛陶金. 白洋淀湿地补水的生态效益评估. 生 态与农村环境学报, 2013, 29(5): 605-611.]

[29] Zhang ZJ, Fei YH, Chen ZY eds. Investigation and evaluation of groundwater sustainable utilization in North China Plain. Beijing: Beijing Geology Press, 2009. [张兆吉, 费宇红, 陈宗宇. 华北平原地下水可持续利用调查评价. 北京: 北 
京地质出版社, 2009.]

[30] Yi YJ, Lin CQ, Tang CH. Hydrology, environment and ecological evolution of Lake Baiyangdian since 1960s. J Lake Sci, 2020，32(5) : 1333-1347. DOI: 10.18307/2020.0500. [易雨君, 林楚戴, 唐彩红. 1960s 以来白洋淀水文、环境、生 态演变趋势. 湖泊科学, 2020, 32(5): 1333-1347.]

[31] Wang CH, Lv DT. Analysis of effect of diversion water from Yuecheng reservoir to Baiyangdian on water environment in Baiyangdian lake. Haihe Water Resources, 2005, (2) : 24-25, 27. [王朝华, 吕丹粀. 引岳济淀对白洋淀水环境影响 分析. 海河水利, 2005, (2): 24-25, 27.]

[32] Xu LJ, Wei JQ. Problems and countermeasures of ecological water replenishment in Baiyangdian Lake. Engineering and Construction, 2014, 28 ( 3) : 305-306, 309. [ 徐丽娟, 魏建强. 白洋淀生态补水存在问题及对策. 工程与建设, $2014,28(3)$ : 305-306, 309.]

[33] Yang W, Yang ZF. Integrating ecosystem-service tradeoffs into environmental flows decisions for Baiyangdian Lake. Ecological Engineering, 2014, 71: 539-550. DOI: 10.1016/j.ecoleng.2014.07.065.

[34] Hebei Provincial Party Committee and Government eds. Baiyangdian ecological environment management and protection plan(2018-2035)，2019. [河北省委、省政府. 白洋淀生态环境治理和保护规划(2018-2035 年), 2019.]

[35] Li SY, Cheng XL, Gu S et al. Hydro-chemical characteristics in the Danjiangkou Reservoir(water source area of the middle route of the south to north water transfer project), China. Environmental Science, 2008, 29(8) : 2111-2116. DOI: 10. 13227/j.hjkx.2008.08.005. [李思悦, 程晓莉, 顾胜等. 南水北调中线水源地丹江口水库水化学特征研究. 环境科 学, 2008, 29(8): 2111-2116.]

[36] Han XD, Zhang Q. Water quality evaluation and analysis of three reservoirs in Baoding city in recent 5 years. Haihe Water Resources, 2016, (3) : 20-22. [ 韩晓东, 张强. 保定市三大水库近 5 年水质评价分析. 海河水利, 2016, (3): 20-22.]

[37] Yuan RQ, Song XF, Wang P et al. Impacts of percolation in Baiyangdian Lake on groundwater. Advances in Water Science, 2012, 23(6) : 751-756. [袁瑞强, 宋献方, 王鹏等. 白洋淀渗漏对周边地下水的影响. 水科学进展, 2012, 23(6): 751-756. ]

[38] Zhang J, Tsujimura M, Song XF et al. Using stable isotopes and major ions to investigate the interaction between shallow and deep groundwater in Baiyangdian Lake Watershed, North China Plain. Hydrological Research Letters, 2016, 10(2): 67-73. DOI: $10.3178 / \mathrm{hrl} .10 .67$.

[39] Zhu MJ, Wang SQ, Kong XL et al. Interaction of surface water and groundwater influenced by groundwater over-extraction, waste water discharge and water transfer in Xiong'an new area, China. Water, 2019, 11 ( 3 ): 539. DOI: 10. 3390/w11030539.

[40] Yuan RQ, Long XT, Wang P et al. Renewal rate of groundwater in the Baiyangdian Lake Basin. Progress in Geography, 2015, 34(3) : 381-388. DOI: 10.11820/dlkxjz.2015.03.013. [袁瑞强, 龙西亭, 王鹏等. 白洋淀流域地下水更新速 率. 地理科学进展, $2015,34(3)$ : 381-388.]

[41] Lv CX, Jia SF, Ji ZH. Dynamics and causes of groundwater table change in plain area of Baiyangdian basin in last 30 years. South-to-North Water Transfers and Water Science \& Technology, 2010, 8(1) : 65-68. [吕晨旭, 贾绍凤, 季志恒. 近 30 年来白洋淀流域平原区地下水位动态变化及原因分析. 南水北调与水利科技, 2010, 8(1):65-68. ]

[42] Wang KL, Li HT, Wu AM et al. An analysis of the evolution of Baiyangdian wetlands in Hebei Province with artificial recharge. Acta Geoscientia Sinica, 2018, 39(5) : 549-558. DOI: 10.3975/cagsb.2018.071102. [王凯霖, 李海涛, 吴爱民 等. 人工补水条件下白洋淀湿地演变研究. 地球学报, 2018, 39(5): 549-558.]

[43] Zhang C, Duan QY, Yeh PJF et al. The effectiveness of the south-to-north water diversion middle route project on water delivery and groundwater recovery in North China plain. Water Resources Research, 2020, 56 (10): e2019WR026759. DOI: $10.1029 / 2019$ WR026759.

[44] Cao WG, Yang HF, Gao YY et al. Prediction of groundwater quality evolution in the Baoding Plain of the SNWDP benefited regions. Journal of Hydraulic Engineering, 2020, 51(8): 924-935. [曹文庚, 杨会峰, 高媛媛等. 南水北调中线受 水区保定平原地下水质量演变预测研究. 水利学报, 2020, 51(8) : 924-935.]

[45] Yuan RQ, Wang SQ, Wang P et al. Changes in flow and chemistry of groundwater heavily affected by human impacts in the Baiyangdian catchment of the North China Plain. Environmental Earth Sciences, 2017, 76(16) : 1-19. DOI: 10.1007/ s12665-017-6918-9.

[46] Xu YQ, Li RM, Liu YS et al. Discussion on the evolution characteristics of phreatic water hydrochemistry of Baoding plain, Hebei, China. Geological Bulletin of China, 2010, 29(8): 1228-1238. [许益青, 李瑞敏, 刘永生等. 保定平原 区潜水水化学演化特征及成因初探. 地质通报, 2010, 29(8)：1228-1238.] 